\title{
Effects of genetic type, stage of lactation, and ripening time on Caciocavallo cheese proteolysis
}

\author{
A. Perna, ${ }^{1}$ A. Simonetti, I. Intaglietta, and E. Gambacorta \\ School of Agricultural, Forestry, Food and Environmental Sciences, University of Basilicata, 10-85100 Potenza, Italy
}

\begin{abstract}
The objective of this experiment was to evaluate the effects of genetic type, stage of lactation, and ripening time on proteolysis in Caciocavallo cheese. One hundred twenty Caciocavallo cheeses made from the milk of 2 breeds, Italian Brown and Italian Holstein and characterized by different stages of lactation were obtained and ripened for 1, 30, 60, 90, and $150 \mathrm{~d}$. Cheese proteolysis was investigated by ripening index (ratio of water-soluble $\mathrm{N}$ at $\mathrm{pH} 4.6$ to total protein, \%) and by the study of degradation of the protein fractions $\left(\alpha_{S 1^{-}}, \beta-\right.$, and para-k-casein), which was determined by densitometric analysis of isoelectric focusing results. The statistical analysis showed a significant effect of the studied factors. Ripening index was higher in Italian Brown Caciocavallo cheese and in cheeses made with early lactation milk, whereas casein solubilization was greater in the first 2 mo of ripening. Isoelectric focusing analysis of cheese samples during ripening showed extensive hydrolysis of caseins. In particular, the protein fraction that underwent major degradation by proteolytic enzymes was $\alpha_{\mathrm{S}_{1}}$-casein, followed by $\beta$-casein, whereas para- $\kappa$-casein was less degraded. Italian Brown cheese showed a lower residual quantity of $\beta$ - and para-k-casein, whereas Italian Holstein cheese showed a lower residual quantity of $\alpha_{\mathrm{S}_{1}}$-casein. In addition, significant interactions of both first and second order were found on both ripening index and degradation of protein fractions. This study demonstrated that the analyzed factors influenced proteolysis of Caciocavallo cheese, which forms the basis of new knowledge that could lead to the production of a pasta filata cheese with specific characteristics.
\end{abstract}

Key words: genetic type, stage of lactation, ripening, proteolysis

\section{INTRODUCTION}

Caciocavallo cheese is a pasta filata cheese of medium or long proteolytic-lipolytic ripening, produced exclu-

Received July 25, 2013.

Accepted December 17, 2013.

${ }^{1}$ Corresponding author: anna.perna@unibas.it sively from raw cow milk and coagulated with lamb rennet paste. Caciocavallo cheese is a typical product of southern Italy and, in the past, it was produced only using milk from autochthonous cow breeds (Podolica, Molisana, and Cinisara cattle). Today, this cheese is produced throughout Italy, mainly using milk from Italian Holstein (IH) and Italian Brown (IB) cattle, which represent the more productive breeds in the Italian livestock scenario. Many authors (Macheboeuf et al., 1993; Auldist et al., 2002; De Marchi et al., 2007) have reported that IB milk shows better cheesemaking characteristics compared with IH milk. In fact, IB milk is characterized by a high index of casein, good colloidal calcium phosphate content, and high frequency of $\kappa-\mathrm{CN} \mathrm{B}$ and $\beta-\mathrm{CN} \mathrm{B}$ alleles, and by optimal properties of rennet coagulation (Mariani et al., 2002). Pasta filata cheese is the result of stretching in hot water (about $80^{\circ} \mathrm{C}$ ) of the acidified curd to about $50^{\circ} \mathrm{C}$. This stretching leads to the alignment of the paracasein matrix and coalescence of fat and moisture into elongated pools parallel to the protein fibers (Battistotti and Corradini, 1993); stretching also influences proteolysis of pasta filata cheeses (De Angelis and Gobbetti, 2011). The physicochemical, nutritional, and organoleptic characteristics of Caciocavallo cheese are closely related to the milk quality, which can change according to genetic and physiological factors of the cow (De Marchi et al., 2008). In fact, milk production and the percentage distribution of its components can greatly change depending on the genetic type (Auldist et al., 2004; De Marchi et al., 2007) and on the stage of lactation, which determines changes in the distribution of individual caseins (Ostersen et al., 1997), in the content of individual whey proteins (Ng-Kwai-Hang et al., 1987), and in rennet properties (Ostersen et al., 1997). Proteolysis, a crucial biochemical process in cheese ripening, occurs through an enzymatic system formed by proteases of different origin: milk (plasmin), rennet (chymosin), milk natural microflora (proteases from mesophilic lactic bacteria), and whey starter bacteria (proteases from thermophilic lactic bacteria) (Fox, 1989; Desmazeaud and Gripon, 1997). The breakdown of caseins by this enzymatic system leads to the formation of peptides that influence cheese texture and flavor during ripening (Creamer and 
Olson, 1982). Many reports describe the influence of the cheesemaking process and the addition of starter and nonstarter cultures on the physicochemical, microbiological, and sensory characteristics of Caciocavallo cheese during ripening (Gobbetti et al., 2002; Melilli et al., 2004; Morea et al., 2007; Sert et al., 2007; Di Cagno et al., 2012; Bonanno et al., 2013), whereas the effect of livestock factors, such as genetic type and stage of lactation, have not yet been well established. The objective of this study, therefore, was to assess the effect of genetic type (GT; Italian Holstein or Italian Brown), stage of lactation (SOL; early: 1-50 d; mid-1: 51-100 d; mid-2: 101-190 d; late: 191-280 d), and ripening time (R; 1, 30, 60, 90, and $150 \mathrm{~d}$ ) on Caciocavallo cheese proteolysis, while also monitoring the degradation of casein fractions.

\section{MATERIALS AND METHODS}

\section{Samples}

One hundred twenty Caciocavallo cheeses produced with milk of 2 breeds (IB and IH) reared indoors on the same farm in the province of Potenza (southern Italy) were used in this experiment. Homogeneous groups were formed after appropriate assessment of the animals in lactation, considering 4 SOL (early: 1-50 d; mid-1: 51-100 d; mid-2:101-190 d; late: 191-280 d) for each GT. All cows used in this experiment received the same food ration, which was calculated according to their daily requirements of maintenance and production. Feeding was based on the use of silage and dried alfalfa hay as the main forage sources and concentrates based on ground corn and soybean meal. The cows were in good clinical condition, and the results obtained from analysis of individual milk showed a mean SCC of $4.89 \log _{10}$ cells $/ \mathrm{mL}$, a value below the legislative limit established by the European Union (2004). For each group (4-5 animals), all milk of the morning milking was collected to make a composite sample, for a total of 8 composite samples $(2 \mathrm{GT} \times 4 \mathrm{SOL})$. On the same dairy farm, 15 Caciocavallo cheeses (average weight of $2.2 \mathrm{~kg}$ each) were produced from each composite sample at the same time and under the same conditions, which were then ripened for different periods: 1, 30, 60, 90, and $150 \mathrm{~d}$.

\section{Cheese Manufacture}

After filtration, the milk was heated to 37 to $38^{\circ} \mathrm{C}$, inoculated $(3 \%, \mathrm{vol} / \mathrm{vol})$ with a natural whey culture (pH 3.8) and coagulated by using lamb rennet paste (177 international milk clotting units $/ \mathrm{mL} ; 40.0 \mathrm{mg} /$ $\mathrm{kg}$ ) for 30 to $40 \mathrm{~min}$. The natural whey starter was obtained by incubating, at $42^{\circ} \mathrm{C}$ for about $24 \mathrm{~h}$, fresh whey derived from a previous cheesemaking of a single mass of milk. The coagulum was first cut coarsely, heated under whey at $45^{\circ} \mathrm{C}$ for $2 \mathrm{~h}$, reduced to particles of about $1.5 \mathrm{~cm}$, and held at room temperature until the $\mathrm{pH}$ reached approximately 5.3. When the acidified curd was ready, it was manually stretched in hot water $\left(70-80^{\circ} \mathrm{C}\right)$. Caciocavallo cheeses were dipped in brine $(27-30 \% \mathrm{NaCl})$ for $24 \mathrm{~h}$ and then ripened at 10 to $12^{\circ} \mathrm{C}$ and 75 to $80 \%$ relative humidity.

\section{Compositional Analysis}

Milk samples were collected and tested for each vat of cheese. Milk samples were taken directly from the cheese vat once the milk had reached a temperature of $31^{\circ} \mathrm{C}$ and before addition of the natural whey culture. Cheese milk samples were analyzed for DM, ash (IDF, 1962), total protein $(\mathbf{T P}$; total $\mathrm{N} \times 6.38)$, NPN $(\mathrm{NPN} \times 6.38)$, casein (casein $\mathrm{N} \times 6.38$; all by Kjeldahl method; AOAC International, 2000), fat (Röse-Gottlieb method; IDF, 1996), and lactose (IDF, 1974). Grated cheese samples were analyzed for DM (oven drying at $102^{\circ} \mathrm{C}$; IDF, 1982), TP (Kjeldahl method; IDF, 1964), Ca (Gazzetta Ufficiale, 1986), P (IDF, 1987), fat and ash (AOAC, 1990). Water-soluble N (WSN) at pH 4.6 $(\mathrm{WSN} \times 6.38)$ and $12 \%$ TCA-soluble N $($ TCASN) were separated using the procedure proposed by Gripon et al. (1975) and assessed by the Kjeldahl method. The $\mathrm{pH}$ of each cheese sample, prepared by blending $20 \mathrm{~g}$ of grated cheese with $12 \mathrm{~mL}$ of $\mathrm{H}_{2} \mathrm{O}$ (Standards Australia, 1989), was measured using a $\mathrm{pH}$ meter (model PHM 92, Radiometer, Copenhagen, Denmark) after calibrating with fresh $\mathrm{pH} 4.0$ and 7.0 standard buffers. All milk and cheese samples were analyzed in duplicate.

\section{Ripening Indices}

Using the experimental data generated, 2 proteolytic indices were calculated as ratios between the various soluble fractions prepared and TP: ripening extension index, WSN at $\mathrm{pH}$ 4.6:TP, and ripening depth index, TCASN:TP.

\section{Isoelectric Focusing}

Eight grams of grated cheese was treated with $25 \mathrm{~mL}$ of $9 M$ urea, and the mixture was homogenized and centrifuged $(5,000 \times g, 10 \mathrm{~min})$ to facilitate settling of the precipitate protein and remove the fat. The precipitate was then treated with $\beta$-mercaptoethanol $(0.2 \%$, $\mathrm{vol} / \mathrm{vol}$ ). Isoelectric focusing (IEF) was conducted according to the method described by Trieu-Cuot and Gripon (1981) on a 1-mm-thick polyacrylamide gel (5\% 
acrylamide and $0.15 \%$ bis-acrylamide) to $2 \%$ ampholytes mixed to create a gradient of $\mathrm{pH} 2.5$ to 10 . The prefocusing and focusing were carried out at a constant power of $0.35 \mathrm{~W} / \mathrm{mL}$ of gel and at a voltage limit of $1,200 \mathrm{~V}$. The gel was stained with Coomassie Blue G-250, as reported by Blakesley and Boezi (1977). Protein degradation was assessed by densitometric analysis (UltroScan XL, Pharmacia LKB, Uppsala, Sweden) of the electrophoretic bands to quantify, in percentage terms, degradation of $\alpha_{\mathrm{S1}^{-}}, \beta-$, and para- $\kappa-\mathrm{CN}$. Protein hydrolysis during ripening was expressed as residual quantity (\%) of each considered casein fraction at each ripening timepoint relative to the baseline.

\section{Statistical Analysis}

Statistical analysis was performed by using the general linear model (GLM) procedure of SAS (SAS Institute, 1996), using a 2-factor model without interaction for milk samples:

$$
\mathrm{y}_{i j k}=\mu+\alpha_{i}+\beta_{j}+\varepsilon_{i j k},
$$

where $\mathrm{y}_{i j k}$ is the observation; $\mu$ is the overall mean; $\alpha_{i}$ is the fixed effect of the $i$ th GT $(i=1,2) ; \beta_{j}$ is the fixed effect of the $j$ th SOL ( $j=$ early, mid-1, mid-2, late); and $\varepsilon_{i j k}$ is the random error.A 3 -factor model with interaction was used for cheese samples:

$$
\begin{gathered}
\mathrm{y}_{i j k l}=\mu+\alpha_{i}+\beta_{j}+\gamma_{k}+\text { first-order interactions } \\
+ \text { second-order interactions }+\varepsilon_{i j k l},
\end{gathered}
$$

where $\mathrm{y}_{i j k l}$ is the observation; $\mu$ is the overall mean; $\alpha_{i}$ is the fixed effect of the $i$ th GT $(i=1,2) ; \beta_{j}$ is the fixed effect of the $j$ th SOL $\left(j=\right.$ early, mid- 1 , mid-2, late); $\gamma_{k}$ is the fixed effect of the $k$ th ripening time $(\mathrm{R} ; k=1,2$, $3,4,5)$; and $\varepsilon_{i j k l}$ is the random error. Percentage data were subjected to angular transformation before statistical analysis. Student's $t$-test was used to compare all the variables. Differences between means at the $95 \%$ ( $P$ $<0.05)$ confidence level were considered statistically significant.

\section{RESULTS AND DISCUSSION}

\section{Milk Composition}

The chemical composition of 8 composite milk samples $(2 \mathrm{GT} \times 4 \mathrm{SOL})$ is shown in Table 1 . Milk from IB showed fat, TP, and CN contents higher $(P$ $<0.05)$ than milk from IH. The higher $\mathrm{CN}$ content found in IB milk is in agreement with that reported by other authors (Malossini et al., 1996; Mariani et al.,
2001; Malacarne et al., 2006; De Marchi et al., 2007) in both milk individual and mass samples. The NPN and lactose contents were not statistically different between the $2 \mathrm{GT}$, in contrast to results reported by Malacarne et al. (2006). Fat and protein content of milk varied with SOL (Table 1), which is in line with results of other authors (Rogers and Stewart, 1982; Kefford et al., 1995; Auldist et al., 1996), even though it is difficult to make direct comparisons between our results and available literature data because the time intervals (days) that defined the different stages of lactation were different from those reported in other studies. In particular, TP content during lactation increased from $3.50 \mathrm{~g} / 100 \mathrm{~g}$, in early-lactation milk, to $3.85 \mathrm{~g} / 100 \mathrm{~g}$, in late-lactation milk. In addition, fat content showed the same trend, although a significant decrease occurred in mid-1-lactation milk. Lactose content was higher in early-lactation milk (4.86 g/100 g; $P<0.05)$, whereas lactose content was constant in other SOL $(4.65 \mathrm{~g} / 100$ g). O'Keeffe (1984) found lactose content in late lactation milk to be lower than we did. Those authors also reported that the low lactose content could be due to the low yield of cows. Contents of NPN and CN were not statistically affected by SOL.

\section{Physicochemical Characteristics and Ripening Index of Caciocavallo Cheese}

The physicochemical characteristics and ripening index of Caciocavallo cheese made from IB and IH milk at different SOL and at different ripening times are shown in Table 2. Overall, cheeses had average values for fat and TP of 46 and $45 \mathrm{~g} / 100 \mathrm{~g}$ of DM, respectively, which were higher than those found in Caciocavallo Ragusano cheese (Licitra et al., 2000) and in Caciocavallo Pugliese cheese (Gobbetti et al., 2002). Significant effects related to GT, SOL, and R were found regarding analyzed physicochemical parameters. Genetic type significantly influenced the chemical characteristics of the Caciocavallo cheese: DM content was higher in IH cheese $(+3.8 \% ; P<0.05)$ than in IB cheese, thus showing a lesser capacity to retain water in the caseous structure. Cheese from IB showed higher fat and TP contents $(+1.4$ and $+1.3 \%$, respectively; $P<0.05)$ than IH cheese, in agreement with results reported by Mariani et al. (2002). Even SOL influenced the chemical characteristics of Caciocavallo cheese (Table 2): cheeses made from early-lactation milk presented DM and WSN at pH 4.6 contents higher than cheeses made from milk at other SOL. The fat content in cheese from early-lactation milk was greater than that made from milk at other SOL, although no significant difference was found between early- and late-lactation milk. In contrast, many researchers (Lucey et al., 1992; Kefford 
Table 1. Chemical composition of Italian Brown and Italian Holstein milk at different stages of lactation

\begin{tabular}{|c|c|c|c|c|c|c|c|}
\hline \multirow{2}{*}{$\begin{array}{l}\text { Parameter, } \\
\mathrm{g} / 100 \mathrm{~g}\end{array}$} & \multicolumn{2}{|c|}{ Genetic type $^{1}$} & \multicolumn{4}{|c|}{ Stage of lactation ${ }^{2}$} & \multirow[b]{2}{*}{ SEM } \\
\hline & IB & $\mathrm{IH}$ & Early & Mid-1 & Mid-2 & Late & \\
\hline DM & $13.53^{\mathrm{a}}$ & $12.55^{\mathrm{b}}$ & 13.09 & 12.73 & 12.98 & 13.36 & 0.14 \\
\hline Fat & $4.19^{\mathrm{a}}$ & $3.60^{\mathrm{b}}$ & $3.99^{\mathrm{a}}$ & $3.67^{\mathrm{b}}$ & $3.87^{\mathrm{ab}}$ & $4.05^{\mathrm{a}}$ & 0.07 \\
\hline Total protein & $3.91^{\mathrm{a}}$ & $3.48^{\mathrm{b}}$ & $3.50^{\mathrm{a}}$ & $3.71^{\mathrm{ab}}$ & $3.70^{\mathrm{ab}}$ & $3.85^{\mathrm{b}}$ & 0.07 \\
\hline Lactose & 4.66 & 4.74 & $4.86^{\mathrm{a}}$ & $4.63^{\mathrm{b}}$ & $4.64^{\mathrm{b}}$ & $4.68^{\mathrm{b}}$ & 0.03 \\
\hline Ash & $0.76^{\mathrm{a}}$ & $0.73^{\mathrm{b}}$ & $0.74^{\mathrm{a}}$ & $0.71^{\mathrm{b}}$ & $0.76^{\mathrm{c}}$ & $0.77^{\mathrm{d}}$ & 0.01 \\
\hline NPN & 0.48 & 0.47 & 0.44 & 0.44 & 0.50 & 0.52 & 0.01 \\
\hline Casein & $2.84^{\mathrm{a}}$ & $2.43^{\mathrm{b}}$ & 2.46 & 2.65 & 2.66 & 2.78 & 0.06 \\
\hline
\end{tabular}

${ }^{\mathrm{a}-\mathrm{d}}$ Values in the same row, for each factor, with different superscripts were significantly different $(P<0.05)$.

${ }^{1} \mathrm{IB}=$ Italian Brown; $\mathrm{IH}=$ Italian Holstein.

${ }^{2}$ Early $=1-50 \mathrm{~d}$; Mid-1 $=51-100 \mathrm{~d}$; Mid-2 $=101-190 \mathrm{~d}$; Late $=191-280 \mathrm{~d}$.

et al., 1995) have found no significant difference in the DM content of cheeses made with milk at different SOL. The DM content increased differently depending on ripening time (Table 2): the increase was greater $(+17 \%)$ from d 1 to 30 , whereas the increase was less pronounced (less than $+8 \%$ ) in the subsequent periods (30-60 d, 60-90 d, and 90-150 d). The $\mathrm{pH}$ value was influenced by all considered factors $(P<0.001)$; in particular, it was higher in IB cheese and in cheeses made from late-lactation milk $(P<0.05)$. This last result is in agreement with Lucey et al. (1992), who reported that cheeses made from late-lactation milk showed a higher $\mathrm{pH}$ value. Also, $\mathrm{pH}$ value changed with ripening time: 5.79 after salting, 5.66 at $30 \mathrm{~d}$, and 5.93 at $150 \mathrm{~d}$ of ripening $(P<0.05)$. This trend is a consequence of the transformation of residue lactose into lactic acid, followed by an increase in $\mathrm{pH}$ because of the buffer effect of milk salts transferred in the cheese. The average $\mathrm{pH}$ value found in our samples was higher than that found in Caciocavallo Ragusano cheese (Licitra et al., 2000) and in Turkish Kaşar cheese (Sert et al., 2007). The relevant process during cheese ripening is protein hydrolysis, which results in an increase of WSN at pH 4.6 and TCASN content (Hayaloglu et al., 2005). The WSN at $\mathrm{pH} 4.6$ increased from $2.44 \mathrm{~g} / 100 \mathrm{~g}$ at $\mathrm{d}$ 1 of ripening to $7.19 \mathrm{~g} / 100 \mathrm{~g}$ at $\mathrm{d} 150$, in agreement with results reported by Perna et al. (2005) in Jersey cheeses. The TCASN value increased from $0.51 \mathrm{~g} / 100$ $\mathrm{g}$ at $\mathrm{d} 1$ to $4.82 \mathrm{~g} / 100 \mathrm{~g}$ at $\mathrm{d} 150$. As expected, the TCASN content was lower than that of WSN; TCASN accounts mainly for small peptides (2-20 residues) and free amino acids (Kuchroo and Fox, 1982). The TCASN fraction is regarded as an index of ripening depth and is composed of peptides that are a part of the WSN fraction and that will precipitate in the presence of $12 \%$ TCA. Based on the ANOVA results, significant interactions of both first and second order were found (Table 2 ). However, no GT $\times \mathrm{R}$ or SOL $\times \mathrm{R}$ interactions were detected for DM and TP contents, whereas all analyzed physicochemical parameters, except WSN at $\mathrm{pH} 4.6$ and TCASN, were influenced by 3 -way interactions $(P$ $<0.05)$. The WSN fraction contains small molecules of proteins (noncasein), peptides, and free amino acids, and is commonly used as an index of ripening (Guinee and Fox, 1993), calculated as ratio percentage of WSN at $\mathrm{pH} 4.6$ to the TP of cheese, to assess the state of maturation (Fallico et al., 2004; Piraino et al., 2004; Cocker et al., 2005). Reville and Fox (1978), in Cheddar cheese, identified the ratio of WSN at $\mathrm{pH} 4.6$ to TP to be a good indicator of maturity in young and medium aged (less than 6 mo old) cheese and TCASN:TP ratio to be a good indicator in mature cheese. Ripening index, the ratio of WSN at $\mathrm{pH} 4.6$ to TP, was affected by all factors considered in the current study (Table 2; $P$ $<0.001$ ), and significant interactions of both first and second order were found. During ripening, the index increased progressively, from $11.48 \%$ at the beginning of ripening to $23.43 \%$ at the end of trial $(P<0.05)$, and this trend was in agreement with Sert et al. (2007) in Kaşar cheese. Casein solubilization was particularly important in the first $60 \mathrm{~d}$ of ripening, with an increase in the index of about $25 \%$ in the d 1-30 period and an increase of about $21 \%$ in the d $30-60$ period. Subsequently, in the d 60-90 and d 90-150 periods, the degree of casein solubilization was less intense (about 14 and $18 \%$, respectively). Caciocavallo cheese from IB showed a higher ripening index than did Caciocavallo cheese from IH $(18.25$ and $16.36 \% ; P<0.05)$. In addition, a GT $\times \mathrm{R}$ interaction $(P<0.05)$ was detected: in IB cheese, casein solubilization was greater between 1 and $30 \mathrm{~d}(+3.63$ percentage units) and between 90 and $150 \mathrm{~d}$ (+4.06 percentage units), whereas in IH cheese, the greatest proteolytic degradation occurred between 30 and $60 \mathrm{~d}(+2.64$ percentage units $)$ and between 90 and $150 \mathrm{~d}(+3.08$ percentage units). The greater casein solubilization in IB cheese in the first ripening period may be due to the higher moisture present in the starting product that influences protease activity, to differ- 
ent accessibility of the cheese to exogenous proteases, and to different enzyme concentrations (Fallico et al., 2004). Furthermore, genetic variants of caseins are an important differential characteristic because they influence cheese structure and, therefore, the action of proteolytic enzymes during ripening (Mariani et al., 2002). Caciocavallo cheeses made from early-lactation milk presented the highest ripening index $(P<0.05)$, whereas those made with mid-2-lactation milk showed the lowest value (Table 1 ). In addition, a $\mathrm{SOL} \times \mathrm{R}$ interaction $(P<0.001)$ was detected: cheeses made from late-lactation milk had the highest ripening index at all ripening times. This could be due to greater moisture in these cheeses that, together with greater $\mathrm{pH}$ value, created the best conditions for enzyme activity (Coulon et al., 2004). It is well known that the animal's physiological state is a major factor affecting variation for milk components, and that it influences the action of endogenous and exogenous proteases. In particular, late-lactation cows are in a state of physiological stress due, in part, to the hormonal balance relating to gestation, which leads to restriction of food intake and reduction of milk production, because fetal growth causes a depletion of the dairy components of milk (Ostersen et al., 1997). Moreover, late-lactation milk has a greater plasmin concentration due to increased cellular permeability of mammary tissue following mammary cell involution (Coulon et al., 2004). However, GT $\times$ SOL and 3 -way interactions $(P<0.001)$ were detected for ripening index. The highest index was detected in $\mathrm{IH}$ cheeses made from early-lactation milk $(24.09 \%)$ and in IB cheeses made from late-lactation milk (21.36\%).

\section{Electrophoretic Profiles of Cheeses}

Isoelectric focusing analysis was used to study proteolysis in Caciocavallo cheeses, and protein degradation was assessed by densitometric analysis of IEF results. The residual quantities (\%) of $\alpha_{\mathrm{S1}^{-}}, \beta$-, and para- $\kappa_{-} \mathrm{CN}$ are shown in Table 3. Overall, the protein fraction that underwent major proteolysis was $\alpha_{\mathrm{S}_{1}} \mathrm{CN}$, followed by $\beta-\mathrm{CN}$, in agreement with results reported by Marcos et al. (1979), whereas para- $-\mathrm{CN}$ was less degraded. Many studies report that $\alpha_{S_{1}}$ CN is the principal substrate of commercial rennets (Fox, 1989; Gobbetti et al., 2002). The degradation of casein fractions was affected by ripening time $(P<0.001)$ : $\alpha_{\mathrm{S}_{1}} \mathrm{CN}$ showed a residual quantity of about $46 \%$, after $30 \mathrm{~d}$ of ripening and approximately $15 \%$ at the end of ripening, for a total degradation of about $85 \%$. The residual quantity of $\beta-\mathrm{CN}$ at d 150 of ripening was approximately $40 \%$, in agreement with Milanovic et al. (1998). During ripening, chymosin has also the ability to hydrolyse $\beta-\mathrm{CN}$, although the high temperatures used for stretching $\left(80^{\circ} \mathrm{C}\right)$ limit residual coagulant activity (De Angelis and Gobbetti, 2011). However, many authors have reported that residual rennet activity may be significant in cooked, long-ripened cheeses, as it probably reactivates after cheese making (Delacroix-Buchet and Fournier, 1992; Hayes et al., 2002, 2004a,b). $\beta$-Casein is the principal substrate of plasmin, which is heat stable and not inactivated under the time, temperature, and $\mathrm{pH}$ conditions likely to occur during stretching (Gobbetti et al., 2002). The residual quantity of para-k-CN (the insoluble part of $\kappa-\mathrm{CN}$ ) at the end of the ripening was approximately 55\%. Many authors (Green and Foster, 1974; Swaisgood, 1992) have reported that para-к-CN has a greater resistance to degradation by chymosin due to its high degree of secondary structure compared with the other caseins. Genetic type influenced protein degradation $(P<0.05$; Table 3$)$ : IH cheese showed greater $\alpha_{\mathrm{S}_{1}} \mathrm{CN}$ degradation, whereas IB cheese showed a greater degradation of both $\beta$ - and para- $\kappa-\mathrm{CN}(P$ $<0.05)$. The lower residual quantity of both $\beta$ - and para-k-CN in IB Caciocavallo cheese was probably due to greater $\mathrm{pH}$ and moisture content that influenced its susceptibility to hydrolysis by proteases (Creamer, 1985). Stage of lactation significantly influenced the degradation of both $\alpha_{\mathrm{S1}^{-}}$and $\beta-\mathrm{CN}(P<0.001)$. No significant effect related to SOL was found regarding para-k-CN degradation. Cheeses made from early- and mid-1-lactation milk showed a lower residual quantity of $\alpha_{\mathrm{S} 1}-\mathrm{CN}(P<0.05)$, in agreement with Sapru et al. (1997), who showed that hydrolysis of $\alpha_{\mathrm{S} 1}-\mathrm{CN}$ was higher in cheese made from early lactation milk (75-90 d). In contrast, cheeses made from mid-2- and late-lactation milk showed a lower residual quantity of $\beta-\mathrm{CN}(P<0.05)$. The greater $\beta-\mathrm{CN}$ hydrolysis in these cheeses is closely linked to the increase of the plasmin concentration in the late-lactation milk (Bastian and Brown, 1996). A significant GT $\times$ SOL interaction $(P<0.001)$ was detected for $\alpha_{\mathrm{S} 1}-\mathrm{CN}$ degradation: IB cheeses made with mid-2- and late-lactation SOL milk showed a greater residual quantity (38.7 and $36.1 \%$, respectively) than those made with early- and mid1-lactation milk (26.9 and $28.6 \%$, respectively), whereas no significant difference was found among IH cheeses made with milk at different stages of lactation (30.7, $29.2,31.0$, and $28.6 \%$ for early, mid- 1 , mid- 2 , and late lactation, respectively). An interaction of GT $\times \mathrm{R}(P<$ $0.001)$ was detected on $\beta-\mathrm{CN}$ degradation: the residual quantity, at all ripening times, was lower in IB cheeses (78.4, 64.6, 42.4, and $29.4 \%$ at $30,60,90$, and $150 \mathrm{~d}$ of ripening, respectively), than in $\mathrm{IH}$ cheeses $(84.4,73.5$, 63.2 , and $50.4 \%$ at $30,60,90$, and $150 \mathrm{~d}$ of ripening, respectively). No significant effects related to first-order interactions were found regarding residual quantity of para-k-CN. In addition, no significant 3 -way interac- 
Table 2. Physicochemical characteristics $(\mathrm{g} / 100 \mathrm{~g}$ unless otherwise stated) and ripening index of Caciocavallo cheese made from Italian Brown and Italian Holstein milk at different stages of lactation and different ripening times

\begin{tabular}{|c|c|c|c|c|c|c|c|c|c|c|c|c|c|}
\hline \multirow[b]{2}{*}{ Parameter } & \multicolumn{2}{|c|}{$\begin{array}{l}\text { Genetic type }^{1} \\
\quad(\mathrm{GT})\end{array}$} & \multicolumn{4}{|c|}{ Stage of lactation ${ }^{2}$ (SOL) } & \multicolumn{5}{|c|}{ Ripening, d (R) } & \multirow[b]{2}{*}{ SEM } & \multirow[b]{2}{*}{ Effect } \\
\hline & IB & $\mathrm{IH}$ & Early & Mid-1 & Mid-2 & Late & 0 & 30 & 60 & 90 & 150 & & \\
\hline of cheeses & 60 & 60 & 30 & 30 & 30 & 30 & 24 & 24 & 24 & 24 & 24 & & \\
\hline $\mathrm{M}$ & 57.81 & 60.02 & $61.68^{\mathrm{a}}$ & $58.03^{\mathrm{b}}$ & $58.45^{\mathrm{b}}$ & $57.50^{\mathrm{b}}$ & $47.43^{\mathrm{a}}$ & $55.74^{\mathrm{b}}$ & $59.97^{c}$ & $63.44^{\mathrm{d}}$ & $68.00^{\mathrm{e}}$ & 0.71 & $\begin{array}{l}\mathrm{GT}^{* * *}, \mathrm{R}^{* * *}, \mathrm{SOL}^{* * *}, \mathrm{GT} \times \mathrm{SOL}^{* * *}, \\
\mathrm{GT} \times \mathrm{SOL} \times \mathrm{R}^{* * *}\end{array}$ \\
\hline at & 46.34 & 45.68 & $46.32^{\mathrm{a}}$ & $45.68^{\mathrm{b}}$ & $45.80^{\mathrm{b}}$ & $46.23^{\mathrm{a}}$ & $21.82^{\mathrm{a}}$ & $25.65^{\mathrm{b}}$ & $27.60^{\mathrm{c}}$ & $29.19^{\mathrm{d}}$ & $31.29^{\mathrm{e}}$ & 0.32 & $\begin{array}{l}\mathrm{GT}^{* * *}, \mathrm{R}^{* * *}, \mathrm{SOL}^{* * *}, \mathrm{GT} \times \mathrm{SOL} * * * \\
\mathrm{GT}^{* *} \mathrm{R}^{*}, \mathrm{SOL} \times \mathrm{R}^{* * *}, \mathrm{GT} \times \mathrm{SOL} \times \\
\mathrm{R}^{* * *}\end{array}$ \\
\hline Total protein $(\mathrm{TP})$ & 45.37 & 44.77 & $45.10^{\mathrm{a}}$ & $44.63^{\mathrm{b}}$ & $45.01^{\mathrm{a}}$ & $45.50^{\mathrm{a}}$ & $21.38^{\mathrm{a}}$ & $25.12^{\mathrm{b}}$ & $27.03^{\mathrm{c}}$ & $28.59^{\mathrm{d}}$ & $30.64^{\mathrm{e}}$ & 0.32 & $\begin{array}{l}\mathrm{GT}^{* *}, \mathrm{R}^{* * *}, \mathrm{SOL}^{* * *}, \mathrm{GT} \times \mathrm{SOL}^{* * *} \\
\mathrm{GT} \times \mathrm{SOL} \times \mathrm{R}^{*}\end{array}$ \\
\hline Ash & 7.71 & 8.43 & $7.94^{\mathrm{a}}$ & $8.67^{\mathrm{b}}$ & $7.99^{\mathrm{a}}$ & $7.77^{\mathrm{a}}$ & $3.84^{\mathrm{a}}$ & $4.51^{\mathrm{b}}$ & $4.85^{\mathrm{bc}}$ & $5.13^{\mathrm{c}}$ & $5.50^{\mathrm{c}}$ & 0.08 & $\begin{array}{l}\mathrm{GT}^{* * *}, \mathrm{R}^{* * *}, \mathrm{SOL}^{*}, \mathrm{GT} \times \mathrm{SOL}^{*}, \mathrm{SOL} \\
\times \mathrm{R}^{* * *}, \mathrm{GT} \times \mathrm{SOL} \times \mathrm{R}^{* * *}\end{array}$ \\
\hline Water-soluble N (WSN) at pH 4.6 & 8.49 & 7.55 & $8.75^{\mathrm{a}}$ & $7.70^{\mathrm{b}}$ & $7.15^{\mathrm{c}}$ & $8.40^{\mathrm{d}}$ & $2.44^{\mathrm{a}}$ & $3.59^{\mathrm{b}}$ & $4.70^{\mathrm{c}}$ & $5.67^{\mathrm{d}}$ & $7.19^{\mathrm{e}}$ & 0.19 & $\begin{array}{l}\mathrm{GT}^{* * *}, \mathrm{R}^{* * *}, \mathrm{SOL}^{* * *}, \mathrm{GT} \times \mathrm{SOL}^{* * *} \\
\mathrm{GT} \times \mathrm{R}^{* *}\end{array}$ \\
\hline TCA-soluble N (TCASN) & 5.02 & 4.14 & $5.22^{\mathrm{a}}$ & $4.27^{\mathrm{b}}$ & $3.82^{\mathrm{c}}$ & $5.01^{\mathrm{d}}$ & $0.51^{\mathrm{a}}$ & $1.90^{\mathrm{b}}$ & $2.68^{\mathrm{c}}$ & $3.57^{\mathrm{d}}$ & $4.82^{\mathrm{e}}$ & 0.07 & $\begin{array}{l}\mathrm{GT}^{* * *}, \mathrm{R}^{* * *}, \mathrm{SOL}^{* * *}, \mathrm{GT} \times \mathrm{SOL}^{* * *} \\
\mathrm{GT} \times \mathrm{R}^{* *}\end{array}$ \\
\hline $\mathrm{Ca}$ & 1.19 & 1.17 & $1.18^{\mathrm{a}}$ & $1.17^{\mathrm{ac}}$ & $1.20^{\mathrm{b}}$ & $1.15^{\mathrm{c}}$ & $0.56^{\mathrm{a}}$ & $0.62^{\mathrm{b}}$ & $0.70^{\mathrm{c}}$ & $0.77^{\mathrm{d}}$ & $0.82^{\mathrm{e}}$ & 0.01 & $\begin{array}{l}\mathrm{GT}^{* * *}, \mathrm{R}^{* * *}, \mathrm{SOL}^{* * *}, \mathrm{GT} \times \mathrm{SOL}^{* * *}, \\
\mathrm{GT}^{* *} \mathrm{R}^{* * *}, \mathrm{SOL} \times \mathrm{R}^{* * *}, \mathrm{GT} \times \mathrm{SOL}^{* *} \times \\
\mathrm{R}^{* * *}\end{array}$ \\
\hline & 0.76 & 0.73 & $0.73^{\mathrm{a}}$ & $1.66^{\mathrm{b}}$ & $1.64^{\mathrm{b}}$ & $1.62^{\mathrm{b}}$ & $0.35^{\mathrm{a}}$ & $0.39^{\mathrm{b}}$ & $0.43^{\mathrm{c}}$ & $0.48^{\mathrm{d}}$ & $0.55^{\mathrm{e}}$ & 0.01 & $\begin{array}{l}\mathrm{GT}^{* * *}, \mathrm{R}^{* * *}, \mathrm{SOL}^{* * *}, \mathrm{GT} \times \mathrm{SOL}^{* * *}, \\
\mathrm{GT}^{* *} \times \mathrm{R}^{* * *}, \mathrm{SOL} \times \mathrm{R}^{* * *}, \mathrm{GT} \times \mathrm{SOL}^{* * *} \times \\
\mathrm{R}^{* *}\end{array}$ \\
\hline $\mathrm{pH}$ & 5.89 & 5.70 & $6.00^{\mathrm{a}}$ & $5.39^{\mathrm{b}}$ & $5.66^{\mathrm{c}}$ & $6.11^{\mathrm{d}}$ & $5.79^{\mathrm{a}}$ & $5.66^{\mathrm{b}}$ & $5.76^{\mathrm{a}}$ & $5.81^{\mathrm{a}}$ & $5.93^{\mathrm{c}}$ & 0.03 & $\begin{array}{l}\mathrm{GT}^{* * *}, \mathrm{R}^{* * *}, \mathrm{SOL}^{* * *}, \mathrm{GT} \times \mathrm{SOL}^{* * *}, \\
\mathrm{GT}^{* *} \mathrm{R}^{*}, \mathrm{SOL} \times \mathrm{R}^{* * *}, \mathrm{GT} \times \mathrm{SOL} \times \\
\mathrm{R}^{* * *}\end{array}$ \\
\hline WSN at $\mathrm{pH} 4.6$ :TP (\%) & 18.25 & 16.36 & $18.91^{\mathrm{a}}$ & $16.74^{\mathrm{b}}$ & $15.67^{\mathrm{c}}$ & $17.92^{\mathrm{d}}$ & $11.48^{\mathrm{a}}$ & $14.37^{\mathrm{b}}$ & $17.44^{\mathrm{c}}$ & $19.81^{\mathrm{d}}$ & $23.43^{\mathrm{e}}$ & 0.56 & $\begin{array}{l}\mathrm{GT}^{* * *}, \mathrm{R}^{* * *}, \mathrm{SOL}^{* * *}, \mathrm{GT} \times \mathrm{SOL} * * * \\
\mathrm{GT}^{* *} \mathrm{R}^{*}, \mathrm{SOL} \times \mathrm{R}^{* * *}, \mathrm{GT} \times \mathrm{SOL} \times \\
\mathrm{R}^{* * *}\end{array}$ \\
\hline TCASN:TP $(\%)$ & 10.67 & 8.44 & $10.87^{\mathrm{a}}$ & $8.93^{\mathrm{b}}$ & $7.86^{\mathrm{c}}$ & $10.56^{\mathrm{d}}$ & $2.31^{\mathrm{a}}$ & $7.48^{\mathrm{b}}$ & $9.83^{\mathrm{c}}$ & $12.56^{\mathrm{d}}$ & $15.60^{\mathrm{e}}$ & 0.18 & $\begin{array}{l}\mathrm{GT}^{* *}, \mathrm{R}^{* * *}, \mathrm{SOL}^{* * *}, \mathrm{GT} \times \mathrm{SOL}^{* * *} \\
\mathrm{GT} \times \mathrm{R}^{* *}, \mathrm{GT} \times \mathrm{SOL} \times \mathrm{R}^{*}\end{array}$ \\
\hline
\end{tabular}

\footnotetext{
${ }^{a-e}$ Values in the same row, for each factor, with
${ }^{1} \mathrm{IB}=$ Italian Brown; IH = Italian Holstein.

${ }^{2}$ Early $=1-50 \mathrm{~d}$; Mid-1 = 51-100 d; Mid-2 = 101-190 d; Late $=191-280 \mathrm{~d}$.

$* P<0.05 ; * * P<0.01 ; * * * P<0.001$.
} 
tion was detected regarding $\alpha_{\mathrm{S1}^{-}}, \beta-$, and para- $\kappa_{-} \mathrm{CN}$ degradation.

\section{CONCLUSIONS}

The physicochemical characteristics and the trend for proteolysis in Caciocavallo cheese were greatly influenced by genetic type, stage of lactation, and ripening. The proteolytic process characterizes the cheese quality, and the products of proteolysis influence the texture, body, and flavor of the cheese. The ripening index was higher in IB Caciocavallo cheese and in cheeses made with early-lactation milk. Casein solubilization was greater in the first $2 \mathrm{mo}$ of ripening. Isoelectric focusing analysis of cheese samples during ripening showed extensive hydrolysis of caseins. In particular, $\alpha_{\mathrm{S}_{1}} \mathrm{CN}$ underwent greater degradation compared with $\beta$ - and para-k-CN. In addition, IB Caciocavallo cheese had lower residual quantities of $\beta$ - and para-k-CN, whereas IH cheese showed a lower residual quantity of $\alpha_{S_{1}}$ CN. This study forms the basis of new knowledge that could lead to the production of a pasta filata cheese with specific characteristics.

\section{REFERENCES}

AOAC. 1990. Association Methods of Analysis. Vol. II. 15th ed. Association of Official Analytical Chemists, Arlington, VA.

AOAC International. 2000. Official Methods of Analysis. 17th ed. AOAC International, Arlington, VA.

Auldist, M., C. Mullins, B. O'Brien, B. T. O'Kennedy, and T. Guinee. 2002. Effect of cow breed on milk coagulation properties. Milchwissenschaft 5:140-143.

Auldist, M. J., S. Coats, B. J. Sutherland, J. J. Mayes, and G. H. McDowell. 1996. Effects of somatic cell count and stage of lactation on raw milk composition and the yield and quality of Cheddar cheese. J. Dairy Res. 63:269-280.

Auldist, M. J., K. A. Johnston, N. J. White, W. P. Fitzsimons, and M. J. Boland. 2004. A comparison of the composition, coagulation characteristics and cheesemaking capacity of milk from Friesian and Jersey dairy cows. J. Dairy Res. 71:51-57.

Bastian, E. D., and R. J. Brown. 1996. Plasmin in milk dairy products: An update. Int. Dairy J. 6:435-457.

Battistotti, B., and C. Corradini. 1993. Italian cheese. Pages 221-243 in Cheese: Chemistry, Physics and Microbiology. Vol. 2. P. F. Fox, ed. Chapman and Hall, London, UK.

Blakesley, R. W., and J. A. Boezi. 1977. A new staining technique for proteins in polyacrylamide gels using Coomassie Brilliant Blue G250. Anal. Biochem. 82:580-582.

Bonanno, A., G. Tornambè, V. Bellina, C. De Pasquale, F. Mazza, G. Maniaci, and A. Di Grigoli. 2013. Effect of farming system and cheesemaking technology on the physicochemical characteristics, fatty acid profile, and sensory properties of Caciocavallo Palermitano cheese. J. Dairy Sci. 96:710-724.

Cocker, C. J., R. A. Crawford, K. A. Johnston, H. Singh, and L. K. Creamer. 2005. Towards the classification of cheese variety and maturity on the basis of statistical analysis of proteolysis data-A review. Int. Dairy J. 15:631-643.

Coulon, J. B., A. Delacroix-Buchet, B. Martin, and A. Pirisi. 2004. Relationships between ruminant management and sensory characteristics of cheese: A review. Lait 84:221-241.

Creamer, L. K. 1985. Water absorption by renneted casein micelles. Milchwissenschaft 40:589-591. 
Creamer, L. K., and N. F. Olson. 1982. Rheological evaluation of maturing Cheddar cheese. J. Food Sci. 47:631-636.

De Angelis, M., and M. Gobbetti. 2011. Pasta-filata cheeses: Traditional pasta-filata cheese. Pages 745-752 in Encyclopedia of Dairy Sciences. Vol. 1. 2nd ed. J. W. Fuquay, P. F. Fox, and P. L. H. McSweeney, ed. Academic Press, San Diego, CA.

De Marchi, M., G. Bittante, R. Dal Zotto, C. Dalvit, and M. Cassandro. 2008. Effect of Holstein Friesian and Brown Swiss breeds on quality of milk and cheese. J. Dairy Sci. 91:4092-4102.

De Marchi, M., R. Dal Zotto, M. Cassandro, and G. Bittante. 2007. Milk coagulation ability of five dairy cattle breeds. J. Dairy Sci. 90:3986-3992.

Delacroix-Buchet, A., and S. Fournier. 1992. Proteolysis and texture of Gruyère-type cheese. II. Influence of chymosin and cheese-making conditions. Lait 72:53-72.

Desmazeaud, J. M., and J. C. Gripon. 1997. General mechanism of protein breakdown during cheese ripening. Milchwissenschaft 32:731-734.

Di Cagno, R., I. De Pasquale, M. De Angelis, and M. Gobbetti. 2012. Accelerated ripening of Caciocavallo Pugliese cheese with attenuated adjuncts of selected nonstarter lactobacilli. J. Dairy Sci. 95:4784-4795

European Union. 2004. Regulation (EC) $\mathrm{N}^{\circ} 853 / 2004$ of 29 April 2004 laying down specific rules for food of animal origin. Off. J. L226:22-82.

Fallico, V., P. L. H. McSweeney, K. J. Siebert, J. Horne, S. Carpino, and G. Licitra. 2004. Chemometric analysis of proteolysis during ripening of Ragusano cheese. J. Dairy Sci. 87:3138-3152.

Fox, P. F. 1989. Proteolysis during cheese manufacture and ripening. J. Dairy Sci. 72:1379-1400.

Gazzetta Ufficiale. 1986. Metodi ufficiali di analisi per i formaggi. G.U. L 229. Ministero dell'Agricoltura e delle Foreste (MAF), Rome, Italy.

Gobbetti, M., M. Morea, F. Baruzzi, M. R. Corbo, A. Maturante, T. Considine, R. Di Cagno, T. Guinee, and P. F. Fox. 2002. Microbiological, compositional, biochemical and textural characterisation of Caciocavallo Pugliese cheese during ripening. Int. Dairy J. $12: 511-523$.

Green, M. L., and P. D. M. Foster. 1974. Comparison of the rates of proteolysis during ripening of Cheddar cheese made with calf rennet and swine pepsin as coagulants. J. Dairy Res. 41:269-282.

Gripon, J. C., M. J. Desmazeaud, D. Et Le Baes, and J. H. Bergere. 1975. Role of microorganisms and enzymes during ripening. Lait 548:502-516.

Guinee, T. P., and P. F. Fox. 1993. General aspects. Pages 257-302 in Cheese: Chemistry, Physics and Microbiology. Vol. 1. P. F. Fox, ed. Chapman \& Hall, London, UK.

Hayaloglu, A. A., M. Guven, P. F. Fox, and P. L. H. Mcsweeney. 2005. Influence of starters on chemical, biochemical, and sensory changes in Turkish white-brined cheese during ripening. J. Dairy Sci. 88:3460-3474

Hayes, M. G., J. C. Oliveira, P. L. H. McSweeney, and A. L. Kelly 2002. Thermal inactivation of chymosin during cheese manufacture. J. Dairy Res. 69:269-279.

Hynes, E., L. Aparo, and M. C. Candioti. 2004a. Influence of residual milk-clotting enzyme on $\alpha_{\mathrm{s} 1}$-casein hydrolysis during ripening of Reggianito Argentino cheese. J. Dairy Sci. 87:565-573.

Hynes, E., M. C. Candioti, C. A. Zalazar, and P. L. H. McSweeney. 2004b. Rennet activity and proteolysis in Reggianito Argentino hard cooked cheese. Aust. J. Dairy Technol. 59:209-213.

International Dairy Federation. 1962. Dry matter and ash. IDF Standard no. 21. Int. Dairy Fed., Brussels, Belgium.

International Dairy Federation. 1964. Determination of the protein content of processed cheeses products. IDF Standard no. 25. Int. Dairy Fed., Brussels, Belgium.

International Dairy Federation. 1974. Determination of the lactose content of milk. IDF Standard no. 28. Int. Dairy Fed., Brussels, Belgium.

International Dairy Federation. 1982. Cheese and processed cheese: Determination of the total solids content. IDF Reference Method 4A. Int. Dairy Fed., Brussels, Belgium.
International Dairy Federation. 1987. Fromages et fromages fondus: Détermination de la teneur en phosphore total (méthode phosphométrique). IDF Standard no. 33C. Int. Dairy Fed., Brussels, Belgium.

International Dairy Federation. 1996. Determination of fat content of milk. IDF Standard no. 1D. Int. Dairy Fed., Brussels, Belgium.

Kefford, B., M. P. Christian, B. J. Sutherland, J. J. Mayes, and C. Grainger. 1995. Seasonal influences on Cheddar cheese manufacture: Influence of diet quality and stage of lactation. J. Dairy Res. $62: 529-537$

Kuchroo, C. N., and P. F. Fox. 1982. Soluble nitrogen in Cheddar cheese: Comparison of extraction procedures. Milchwissenschaft 37:331-335.

Licitra, G., P. Campo, M. Manenti, G. Portelli, S. Scuderi, S. Carpino, and D. M. Barbano. 2000. Composition of Ragusano cheese during aging. J. Dairy Sci. 83:404-411.

Lucey, J. A., P. S. Kindstedt, and P. F. Fox. 1992. Seasonality: its impact on the production of good quality Mozzarella cheese. Pages 41-48 in 3rd Cheese Symposium, Moorepark Teagasc, Dublin, Ireland. T. M. Cogan, ed. National Dairy Products Centre, Dublin, Ireland.

Macheboeuf, D., J. B. Coulon, and P. D'Hour. 1993. Effect of breed, protein genetic variants and feeding on cows' milk coagulation properties. J. Dairy Res. 60:43-54.

Malacarne, M., A. Summer, E. Fossa, P. Formaggioni, P. Franceschi, M. Pecorari, and P. Mariani. 2006. Composition, coagulation properties and Parmigiano-Reggiano cheese yield of Italian Brown and Italian Friesian herd milks. J. Dairy Res. 73:171-177.

Malossini, F., S. Bovolenta, C. Piras, M. Dalla Rosa, and W. Ventura 1996. Effect of diet and breed on milk composition and rennet coagulation properties. Ann. Zootech. 45:29-40.

Marcos, A., M. A. Esteban, F. Leòn, and J. Fernandez-Salguero. 1979. Electrophoretic patterns of European cheese: Comparison and quantification. J. Dairy Sci. 62:892-900.

Mariani, P., A. Summer, P. Formaggini, and M. Malacarne. 2002. La qualità casearia del latte di differenti razze bovine. La Razza Bruna Italiana. 1:7-13.

Mariani, P., A. Summer, P. Formaggioni, M. Malacarne, and E. Fossa. 2001. Casein content, salt equilibria and rheological properties of bulk milks from different cattle breeds in the production of Parmigiano-Reggiano cheese. Pages 161-168 in Atti: 36th Simposio Internazionale di Zootecnia, Ancona, Italy. MG Editori, Milan, Italy

Melilli, C., D. M. Batbano, M. Caccamo, M. A. Calvo, G. Schembari, and G. Licitra. 2004. Influence of brine concentration, brine temperature, and brine presalting on early gas defects in raw milk pasta filata cheese. J. Dairy Sci. 87:3648-3657.

Milanovic, S., M. Kalab, and M. Caric. 1998. Strucyure of Kaskaval curd manufactured from milk or UF ritentate using enzymes of various origin. Lebenson. Wiss. Technol. 31:377-386.

Morea, M., A. Matarante, R. Di Cagno, F. Baruzzi, and F. Minervini 2007. Contribution of autochthonous non-starter lactobacilli to proteolysis in Caciocavallo Pugliese cheese. Int. Dairy J. 17:525534 .

Ng-Kwai-Hang, K.-F., J. F. Hayes, J. E. Moxley, and H. G. Monardes. 1987. Variation in milk protein concentrations associated with genetic polymorphism and environmental factors. J. Dairy Sci. 70:563-570.

O'Keeffe, A. M. 1984. Seasonal and lactational influences on moisture content of Cheddar cheese. Irish J. Food Sci. Technol. 8:27-37.

Ostersen, S., J. Foldager, and J. E. Hermansen. 1997. Effects of stage of lactation, milk protein and body condition at calving on protein composition and renneting properties of bovine milk. J. Dairy Res. 64:207-219.

Perna, A., M. Palazzo, C. Cosentino, A. Manchisi, and E. Gambacorta. 2005. Jersey breed cows: cCasein genotype and evolution of protein in cheese. Pages 187-193 in Atti: 40 Simposio Internazionale di Zootecnia, Lodi, Italy. From Genome to Proteome in Animal Science. Istituto Sperimentale Italiano "Lazzaro Spallanzani", Lodi, Italy.

Piraino, P., E. Parente, and P. L. H. McSweeney. 2004. Processing of chromatographic data for chemometric analysis of peptides 
from cheese extracts: A novel approach. J. Agric. Food Chem. 52:6904-6911.

Reville, W. J., and P. F. Fox. 1978. Soluble protein in Cheddar cheese: A comparison of analytical methods. Int. J. Food Sci. Technol. 2:67-76.

Rogers, G. L., and J. A. Stewart. 1982. The effects of some nutritional and non-nutritional factors on milk protein concentration and yield. Aust. J. Dairy Technol. 37:26-31.

Sapru, A., D. M. Barbano, J. J. Yun, L. K. Klei, P. A. Oltenacu, and D. K. Bandler. 1997. Cheddar cheese: Influence of milking frequency and stage of lactation on composition and yield. J. Dairy Sci. 80:437-446.

SAS Institute. 1996. SAS User's Guide: Statistics. Version 7. SAS Institute Inc., Cary, NC.
Sert, D., A. Ayar, and N. Akin. 2007. The effects of starter culture on chemical composition, microbiological and sensory characteristics of Turkish Kaşar cheese during ripening. Int. J. Dairy Technol. 60:245-252.

Standards Australia. 1989. Methods of chemical and physical testing in the dairying industry: General methods and principles-Determination of pH. Aust. Stand. AS:2300.1.6. Standards Australia, Sydney, Australia.

Swaisgood, H. E. 1992. Chemistry of the caseins. Pages 63-110 in Advanced Dairy Chemistry. Vol. 1, P. F. Fox, ed. Elsevier Applied Science, London, UK.

Trieu-Cuot, P., and J. C. Gripon. 1981. Electrofocusing and two-dimensional electrophoresis of bovine caseins. J. Dairy Res. 48:303310. 